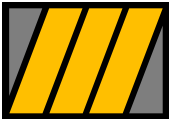

ESCUELA DE NEGOCIOS

Universidad Torcuato Di Tella

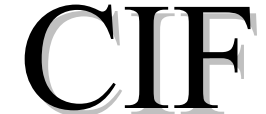

Centro de Investigación en Finanzas

Documento de Trabajo 07/2003

\title{
The Price of Inconvertible Deposits: The Stock Market Boom during the Argentine crisis
}

Eduardo Levy Yeyati

Universidad Torcuato Di Tella

and

Sergio Schmukler

World Bank

and

Neeltje van Horen

World Bank
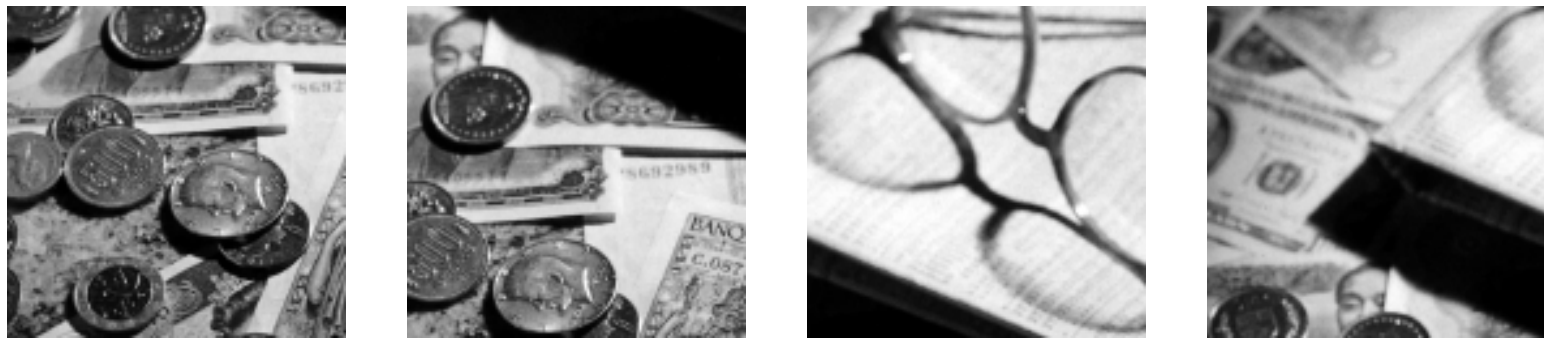

Miñones 2177, C1428ATG Buenos Aires • Tel: 4784.0080 interno 181 y 4787.9394 • Web site: www.utdt.edu/departamentos/empresarial/cif/cif.htm 


\title{
The Price of Inconvertible Deposits: The Stock Market Boom during the Argentine Crisis
}

\author{
Eduardo Levy Yeyati Sergio Schmukler Neeltje Van Horen*
}

April 2003

\begin{abstract}
The Argentine crisis witnessed, among other things, a deposit run, the suspension of deposit convertibility, and a "boom" in the stock market. We argue that this boom reflects the cost that depositors were willing to incur to get their money out of the banking system, in light of the impending risks. This boom was generalized to all stocks and more pronounced in liquid stocks. Furthermore, the boom was a symptom that deposits were effectively restricted and that investors were not able to circumvent capital controls.
\end{abstract}

JEL Classification Codes: F3, G1

Keywords: financial crisis; banking crisis; ADRs; Argentina; capital outflows

\footnotetext{
* Levy Yeyati is with Universidad Torcuato di Tella. Schmukler and Van Horen are with the World Bank. E-mail addresses: ely@utdt.edu, sschmukler@worldbank.org, and nvanhoren@worldbank.org. The findings, interpretations, and conclusions expressed in this paper are entirely those of the authors and do not necessarily represent the views of the World Bank.
} 
During 2001, Argentina faced a currency run that triggered a generalized bank run. ${ }^{1}$ As a result, Argentina suspended convertibility of their bank deposits on December 3 (the so-called "corralito"), ${ }^{2}$ and imposed extensive capital controls, measures that were followed on January 7 by the devaluation of the peso and a compulsory "pesification" and reprogramming of most bank deposits on February 3. Following the establishment of the corralito, the stock market witnessed a "boom" in prices, in contrast with other recent crises, resulting in a cumulative increase of the local stock exchange index of $64 \%$ between the start of the corralito and the devaluation, and a further increase of $50 \%$ by end-2002. Two recent papers by Auguste et al. (2003) and Melvin (2002) attribute this seemingly unexpected development to a boom in stocks of companies with American Depositary Receipts (ADRs) that may have been used as a channel for capital outflows.

In this note, we complement this new literature by showing that the price increase was generalized to all stocks, including stocks with and without ADRs, and more pronounced in liquid stocks. We also argue that this mechanism did not generate capital outflows. Indeed, while ADR stocks did provide a way to migrate equity and obtain in exchange dollars outside Argentina, at most only a small fraction of these stocks were transferred abroad. Instead, the boom reflected the price investors were willing to pay to cash out their inconvertible bank deposits, in light of the impending devaluation, reprogramming, and confiscation risks. As a result, the boom could be interpreted as a consequence of the effectiveness of both the suspension of deposit convertibility and the capital controls.

\footnotetext{
${ }^{1}$ See, for example, De La Torre et al. (2003) and references therein for an analysis of the crisis.

${ }^{2}$ The name corralito ("little fence") was initially adopted because deposits could be transferred freely within the financial system but could not be redeemed in cash and leave the system, beyond a certain limit.
} 


\section{The corralito and the stock market boom}

As shown in Figure 1, the corralito was preceded by a steady decline in reserves and deposits during 2001. The cumulative slide in reserves from January 2001 until November 2001 amounted to a loss of 10.9 billion dollars, paralleled by a loss of 11.5 billion dollars in deposits. The run peaked (possibly in anticipation of the coming controls) on November 30, when deposits and reserves fell by 1.4 and 1.7 billion dollars respectively. The imposition of the corralito, coupled with a ban on capital outflows, significantly halted the decline in both deposits and reserves. ${ }^{3}$

If by November, the abandonment of the fixed parity was judged highly likely, the corralito signaled the practical demise of convertibility and the question was no longer whether a devaluation was inevitable, but rather what the post-devaluation exchange rate would be. Moreover, the perception that the corralito had all but reduced the incentives to run fueled beliefs that deposits would need to be (at least partially) reprogrammed to avoid a banking collapse or hyperinflation, in the event the corralito was lifted. Finally, the option to pesify deposits and loans, already under discussion in policy circles, appeared ever more likely, as a way to avoid generalized defaults. Consequently, the dollarization of deposits was no longer a realistic hedge against exchange rate risk. ${ }^{4}$

There were at least three powerful reasons to leave the corralito: i) the reduced liquidity of bank deposits due to limited convertibility (only within the banking sector)

\footnotetext{
${ }^{3}$ While there were no restrictions on the purchase of dollar bills, right after the imposition of the corralito the supply of dollars was increasingly rationed until December 21, when the foreign exchange market was officially closed.

${ }^{4}$ All of these beliefs eventually materialized. Most time and savings deposits (including those matured in December and shifted to sight accounts) were reprogrammed at a longer duration and dollar deposits were converted at the official (below market) 1.40 peso-dollar exchange rate.
} 
that generated a "cash premium"; ${ }^{5}$ ii) the possible reprogramming of deposits; and iii) the impending devaluation in combination with a threat of pesification.

These reasons generated a new demand for stocks (with and without ADRs), pushing their prices up relative to inconvertible corralito deposits. Stocks were affected by all three factors: stock prices were quoted in illiquid "corralito pesos," stocks were reprogramming-free, and stocks protected investors from a devaluation (as part of their returns were tied to dollar revenues).

This is confirmed by the evolution of market capitalization-weighted portfolios of ADRs and non-ADR stocks (Figure 2). ${ }^{7}$ A closer look reveals that the boom was more pronounced in liquid stocks: the top five most liquid stocks in the portfolio (as determined by their average value traded in the period December 2001 - January 2002) experienced a substantially larger price hike. ${ }^{8}$ As a result, once we restrict attention to the most liquid stocks, the evolution of both portfolios after the imposition of the corralito exhibits a similar pattern.

\section{ADRs, capital controls, and capital outflows}

As argued in previous papers, ADR stocks gave investors the option to exchange inconvertible deposits for U.S. dollars in the international financial centers. However,

\footnotetext{
${ }^{5}$ This premium was regularly measured as the discount rate on checks, which declined gradually as the funds waiting to get out of the corralito fell over the year. By the time the corralito was lifted on December 2, 2002, the discount was about 2 percent.

${ }^{6}$ An investor holding cash and willing to invest in stocks could have, for example, purchased a deposit at a discount and use it to buy the stock. Alternatively, he could have bought the stocks cash, but at a discount.

${ }^{7}$ The results are not affected by the use of alternative weighting schemes.

${ }^{8}$ As the top five ADR stocks are more liquid than the top five non-ADR stocks, one would naturally expect that the price boost would be larger in the former, which was not the case. This seemingly contradicting result can be explained by the fact that the price of ADR stocks in Buenos Aires is also a function of the price of the ADR in New York, which remained relatively stable.
} 
did this fund-shifting mechanism provide a way to circumvent the controls on deposits or on capital outflows? And did investors actually use this fund-shifting alternative to get fresh dollars abroad? We turn to these two questions next.

Even though ADR stocks allowed investors to migrate their stocks to New York, this migration did not mean that controls were circumvented. On the contrary, in normal times this migration is the counterpart of capital inflows to emerging markets, as domestic stocks are exchanged for new funds invested in the country. ${ }^{9}$ While it is unlikely that the capital obtained through migration was repatriated during the crisis, it is still true that these transactions did not entail a decline in the overall level of deposits (which would have been otherwise reflected in a loss of deposits and reserves). Depositors that purchased stocks with inconvertible deposits simply transferred them to previous stocks holders.

The absence of capital outflows can be observed in the data, both in quantities and prices. As Figure 1 shows, after dropping significantly in the pre-crisis period, reserves remained stable once the corralito and other controls were imposed. The drop in deposits, reflecting the cash withdrawal within the limits of the corralito, translated into an increase in currency in circulation.

The effectiveness of capital outflows is also apparent in the ADR premium (the difference between prices of ADR stocks in Buenos Aires and ADRs in New York). As shown in Alaganar and Bhar (2001), under perfect integration the law of one price holds as any price difference is instantaneously arbitraged away. By contrast, market segmentation induced by capital controls, providing they are binding (hence, effective),

\footnotetext{
${ }^{9}$ Investors willing to invest in those countries demand their stocks in international equity markets, among other things. See Claessens et al. (2002), Levine and Schmukler (2003), and the long literature cited therein.
} 
leads to the occurrence of a premium as full arbitrage cannot take place. ${ }^{10}$ The case of Argentina is a good example; the premium was close to zero before the controls were implemented and turned positive thereafter, gradually declining from around $50 \%$ to a value of around $7 \%$ by the end of May (Figure 3). ${ }^{11}$

As ADR stocks were priced in corralito pesos while ADRs were priced in dollars out of the corralito (and out of the country), the ADR premium reflected the three factors previously described plus the premium induced by controls on capital outflows. ${ }^{12}$ Accordingly, the evolution of the premium over time can be traced not only to the realization of the reprogramming and exchange rate risks, but also to the weakening of the cash premium (as the reprogramming of deposits and the steady leakage of unreprogrammed deposits slowly reduced the volume of corralito funds pushing for the exit) and to the relaxation of other controls be end-2002.

Finally, note that, despite the absence of capital outflows, investors could have still taken advantage of ADR stocks to move their funds out of the country through stock migration. We argue that this occurred only to a limited extent. Figure 4 shows that the average trading volume in ADRs in New York was high before the imposition of the corralito, as investors kept selling Argentine stocks abroad while the crisis deepened. With the corralito, by contrast, the trading of ADR stocks in Buenos Aires increased significantly in relative terms, more than doubling the activity in New York (which also

\footnotetext{
${ }^{10}$ The existence of controls does not prevent arbitrage across markets; it just means that the non-arbitrage bands become wider so a non-zero discount can emerge. Depending on the type of control, a positive or negative premium emerges. See Levy Yeyati and Schmukler (1999).

${ }^{11}$ The premium is the percentage difference between the closing dollar price of the stock in Buenos Aires and the closing price of the corresponding ADR in New York. Each stock in the portfolio is weighted by its relative market capitalization.

${ }^{12}$ A crude estimate of the latter is given by the ADR premium of around $15 \%$ by end-February (when the reprogramming and exchange rate risks had already realized) minus a cash premium of about $9 \%$ by the same date (as reported by the Central Bank of Argentina).
} 
represents trades among New York investors). This evidence indicates that only part of the purchases of the underlying stock ended up being transferred abroad during the period. Thus, this fund-shifting ADR-specific motive does not appear to have been a key driver behind the stock market boom.

In sum, the evidence suggests that the boom reflected the desire of depositors to shift their inconvertible deposits out of the banking system, although not necessarily out of the country. In light of this, the boom (as well as the sizeable ADR premium that accompanied it) was a manifestation that the controls imposed were effective.

\section{References}

Alaganar, Vairamuththu, and Ramaprasad Bhar, 2001, "Diversification Gains from ADRs and Foreign Equities: Evidence from Australian Stocks," Journal of International Financial Markets, Institutions, and Money, 11:1, pp. 97-113.

Auguste, Sebastian, Kathryn Dominguez, Herman Kamil, and Linda Tesar, 2003, "CrossBorder Trading as a Mechanism for Implicit Capital Flight: ADRs, CEDEARs, and the Argentine Crisis," previous version appeared as NBER Working Paper No. 9343, November 2002.

Claessens, Stijn, Daniela Klingebiel, and Sergio Schmukler, 2002, “The Future of Stock Exchanges in Emerging Markets," Brookings-Wharton Papers on Financial Services, pp.167-202, also available as CEPR Discussion Paper 3301.

De la Torre, Augusto, Eduardo Levy Yeyati, and Sergio Schmukler, 2003, "Living and Dying with Hard Pegs: The Rise and Fall of Argentina's Currency Board," forthcoming, Economia.

Levine, Ross, and Sergio Schmukler, 2003, "Migration, Spillovers, and Trade Diversion: The Impact of Internationalization on Stock Market Liquidity," NBER Working Paper.

Levy Yeyati, Eduardo, and Sergio Schmukler, 1999, "Effects of Capital Controls on Capital Markets: Evidence from ADRs," mimeo The World Bank and Universidad Torcuato Di Tella.

Melvin, Michael, 2002, "A Stock Market Boom During a Financial Crisis? ADRs and Capital Outflows in Argentina," Arizona State University Working Paper, June. 


\section{Figure 1}

\section{Evolution of Deposits and Reserves}

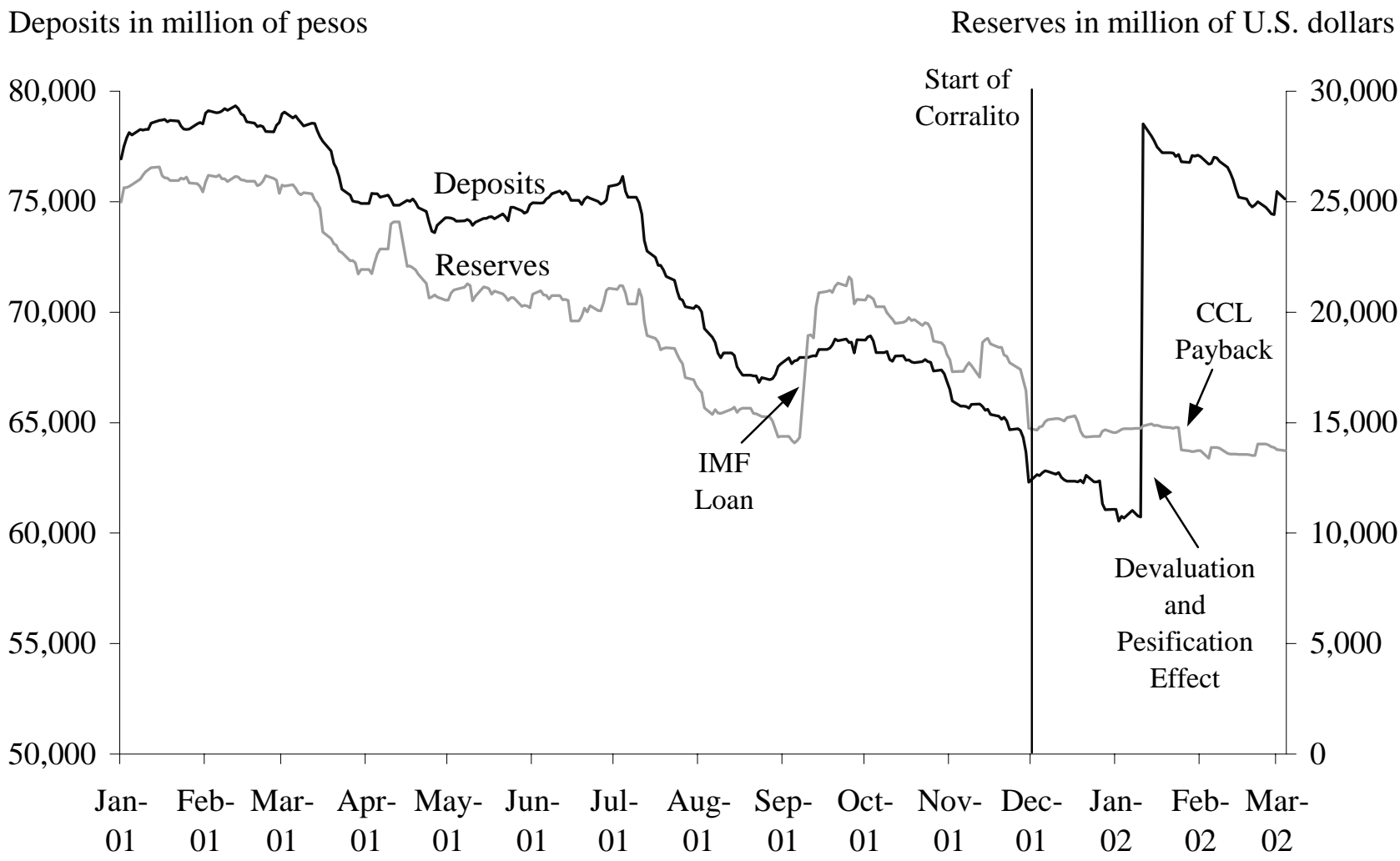

Deposits include dollar and peso deposits held by the private sector. Dollar deposits are converted into pesos using the market exchange rate. The large jump in deposits on January 11, 2002 reflects the combined effect of the devaluation of the exchange rate, increasing the peso value of dollar deposits, and the pesification of dollar deposits at the 1.4 conversion rate. Reserves include gold and currency in possession of the central bank. The increase in reserves on September 10, 2001 is due to the disbursement of an IMF loan, which was deposited in the central bank. The one billion U.S. dollar drop on January 24, 2002 corresponds to the payback of the contigent credit line (CCL).

Sources: Bloomberg and Central Bank of Argentina 
Figure 2

The Boom in the Stock Market

Price of ADR and Non-ADR Portfolios

Price index

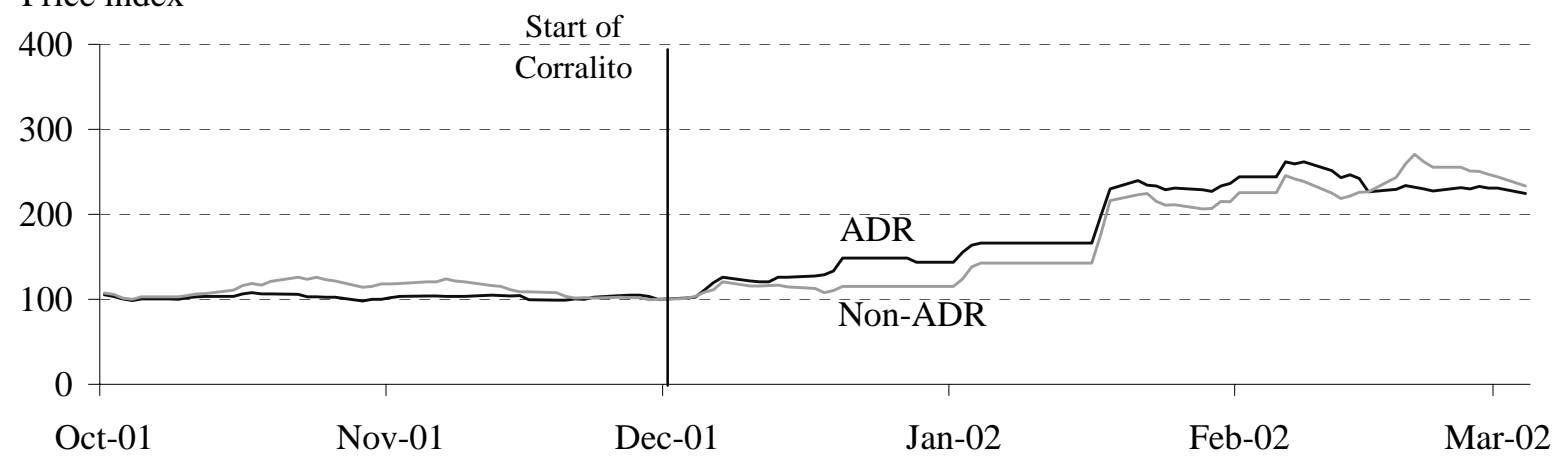

Price of Different ADR Portfolios

Price index

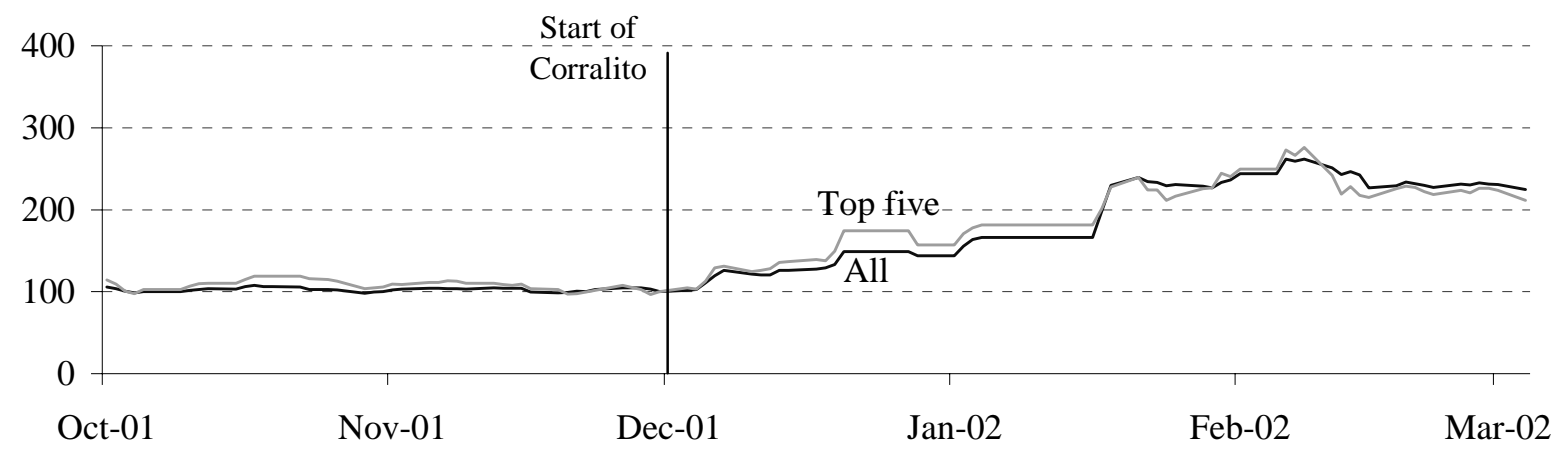

Price of Different Non-ADR Portfolios

Price index

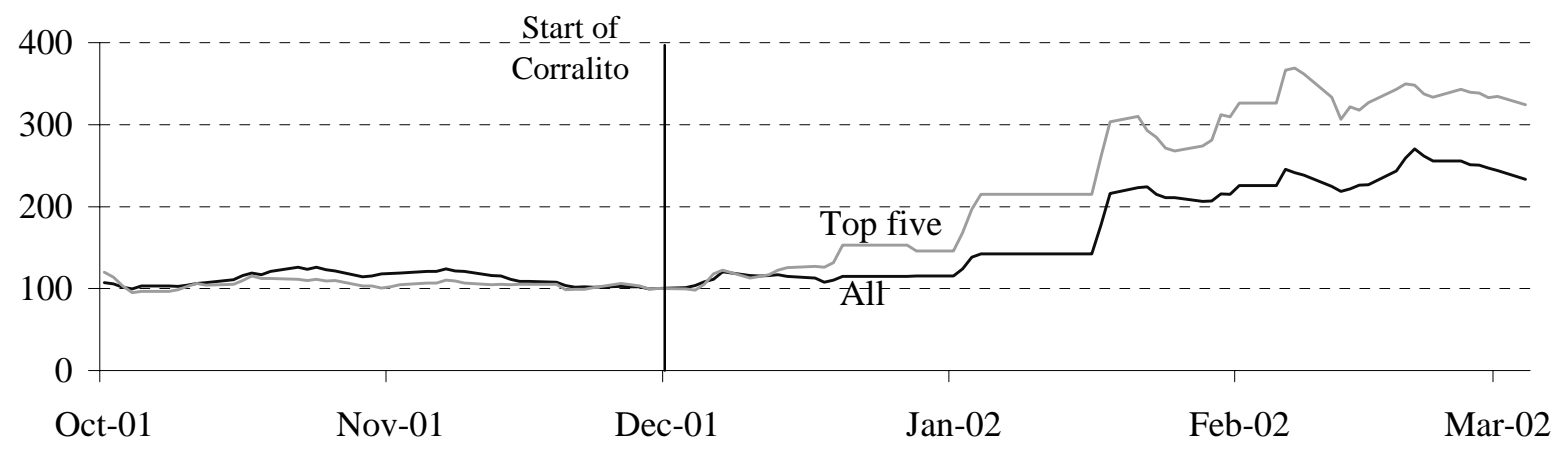

The complete ADR portfolio includes all publicly listed ADR stocks (12 stocks), except Nortel which is highly illiquid. The non-ADR portfolio includes 43 stocks, excluding stocks that were traded less than three days in the first month of the corralito. Each stock in the portfolio is weighted according to its relative market capitalization. The graph in the top panel is similar to the one shown in Auguste et al (2002). Top five refers to the five stocks with the highest average value traded in the period December 2001-January 2002. The Top five ADR stocks includes Banco Frances, Grupo Financiero Galicia, Perez Companc, Siderca, and Telecom Argentina. The Top 5 non-ADR stocks includes Acindar, Atanor, Molinos, Siderar, and Solvay Indupa. All stock prices are taken in pesos. Each index is equal to 100 on November 30, 2001. The flat parts in the graph indicate periods of no trading, as the stock market was closed.

Source: Bloomberg 


\section{Figure 3}

\section{ADR premium}

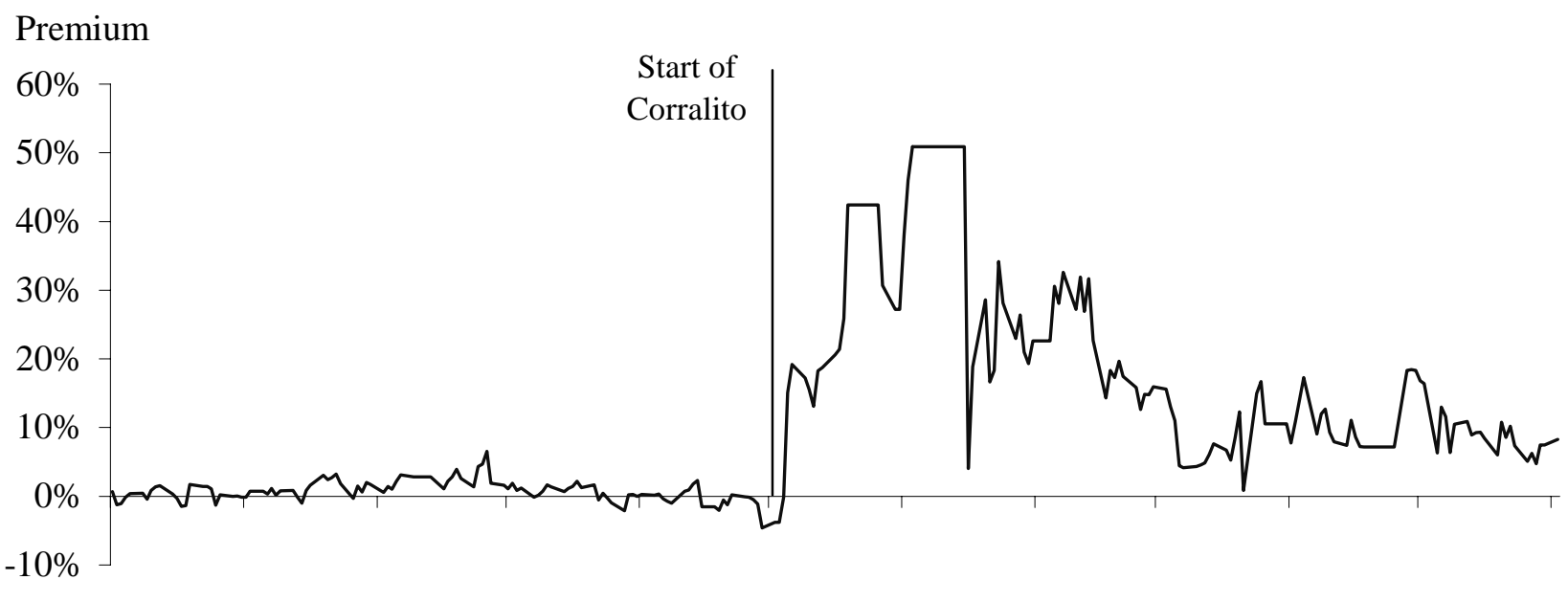

Jul-01 Aug-01 Sep-01 Oct-01 Nov-01 Dec-01 Jan-02 Feb-02 Mar-02 Apr-02 May-02 Jun-02

The graph plots the ADR premium for the portfolio of ADRs (12 stocks). The premium is the percentage difference between the closing dollar price of the stock in Buenos Aires and the closing price of the corresponding ADR in New York. Each stock in the portfolio is weighted by its relative market capitalization. Note that during the sample period there were days when one of the stock markets was closed. On those days, the premium from the last trading day is repeated. The peak premium occurred on January 4, 2002, which coincides with the announcement of President Duhalde that the peg with the dollar would be broken.

Source: Bloomberg 


\section{Figure 4}

Trading in Buenos Aires and New York

Trading volume in million of U.S. dollars

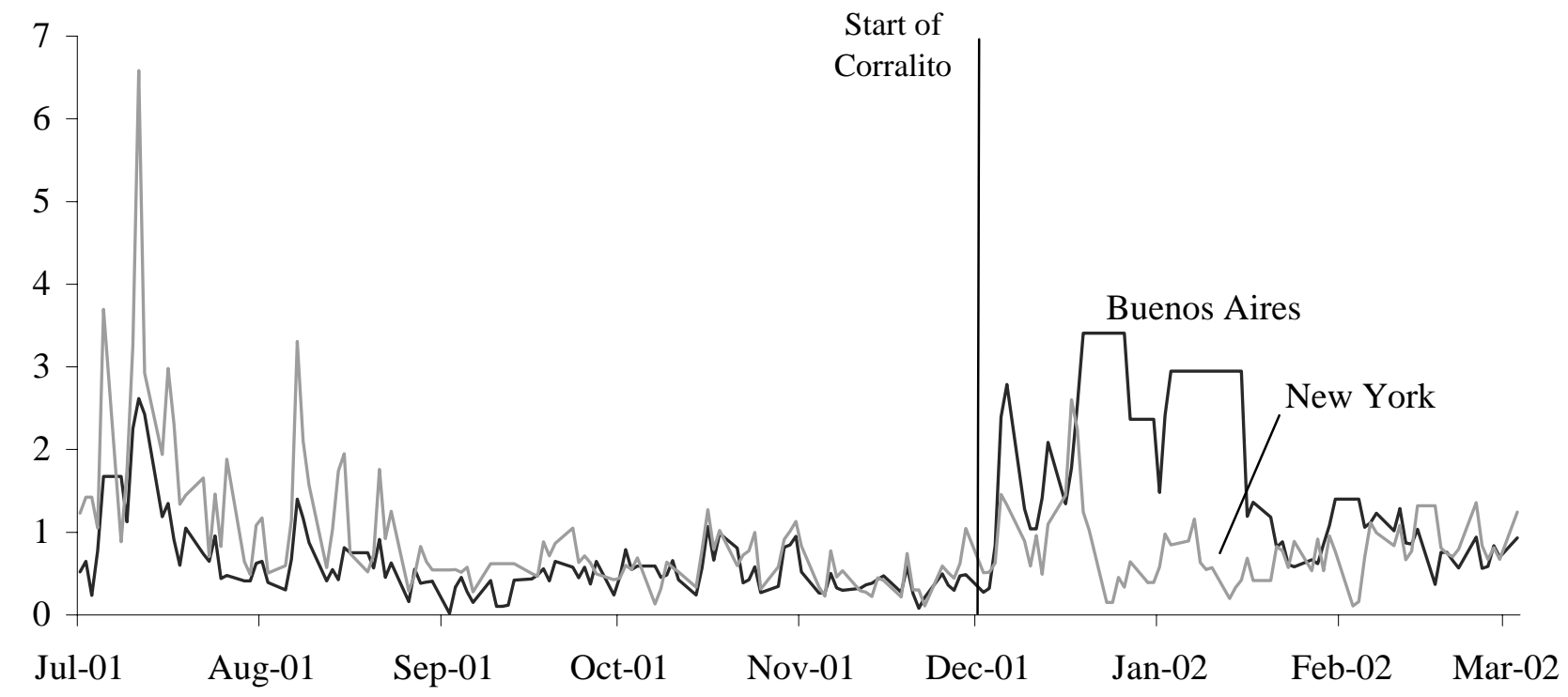

The figure shows the trading volume of the complete ADR portfolio (12 stocks), using the stocks with ADRs for Buenos Aires trading and the corresponding ADRs for New York trading. Each stock is weighted according to its relative market capitalization. On days of no trading the trading volume of the previous trading day is repeated.

Source: Bloomberg 


\section{Universidad Torcuato Di Tella, Business School Working Papers}

\section{Working Papers 2003}

NN16 "Business Cycle and Macroeconomic Policy Coordination in MERCOSUR"

Martín Gonzalez Rozada (UTDT) y José Fanelli (CEDES).

No15 "The Fiscal Spending Gap and the Procyclicality of Public Expenditure"

Eduardo Levy Yeyati (UTDT) y Sebastián Galiani (UDESA).

No14 "Financial Dollarization and Debt Deflation under a Currency Board"

Eduardo Levy Yeyati (UTDT), Ernesto Schargrodsky (UTDT) y Sebastián Galiani (UDESA).

№13 " ¿ Por qué crecen menos los regímenes de tipo de cambio fijo? El efecto de los Sudden Stops", Federico Stuzenegger (UTDT).

№12 "Concentration and Foreign Penetration in Latin American Banking Sectors: Impact on Competition and Risk", Eduardo Levy Yeyati (UTDT) y Alejandro Micco (IADB).

№11 "Default 's in the 1990's: What have we learned?",

Federico Sturzenegger (UTDT) y Punan Chuham (WB).

№10 "Un año de medición del Indice de Demanda Laboral: situación actual y perspectivas",

Victoria Lamdany (UTDT) y Luciana Monteverde (UTDT)

N'09 "Liquidity Protection versus Moral Hazard: The Role of the IMF",

Andrew Powell (UTDT) y Leandro Arozamena (UTDT)

№8 "Financial Dedollarization: A Carrot and Stick Approach", Eduardo Levy Yeyati (UTDT)

No07 "The Price of Inconvertible Deposits: The Stock Market Boom during the Argentine crisis",

Eduardo Levy Yeyati (UTDT), Sergio Schmukler (WB) y Neeltje van Horen (WB)

NN06 "Aftermaths of Current Account Crisis: Export Growth or Import Contraction?",

Federico Sturzenegger (UTDT), Pablo Guidotti (UTDT) y Agustín Villar (BIS)

No5 "Regional Integration and the Location of FDI",

Eduardo Levy Yeyati (UTDT), Christian Daude (UM ) y Ernesto Stein (BID)

N04 "A new test for the success of inflation targeting",

Andrew Powell (UTDT), Martin Gonzalez Rozada (UTDT) y Verónica Cohen Sabbán (BCRA)

No03 "Living and Dying with Hard Pegs: The Rise and Fall of Argentina's Currency Board",

Eduardo Levy Yeyati (UTDT), Augusto de la Torre (WB) y Sergio Schmukler (WB)

No02 "The Cyclical Nature of FDI flows",

Eduardo Levy Yeyati (UTDT), Ugo Panizza (BID) y Ernesto Stein (BID) 
№1 "Endogenous Deposit Dollarization",

Eduardo Levy Yeyati (UTDT) y Christian Broda (FRBNY)

\section{Working Papers 2002}

№15 "The FTAA and the Location of FDI",

Eduardo Levy Yeyati (UTDT), Christian Daude (UM ) y Ernesto Stein ( BID)

No14 "Macroeconomic Coordination and Monetary Unions in a N-country World: Do all Roads

Lead to Rome?"

Federico Sturzenegger (UTDT) y Andrew Powell (UTDT)

№13 "Reforming Capital Requirements in Emerging Countries"

Andrew Powell (UTDT), Verónica Balzarotti (BCRA) y Christian Castro (UPF)

№12 "Toolkit for the Analysis of Debt Problems", Federico Sturzenegger (UTDT)

№11 "On the Endogeneity of Exchange Rate Regimes",

Eduardo Levy Yeyati (UTDT), Federico Sturzenegger (UTDT) e lliana Reggio (UCLA)

№10 "Defaults in the 90's: Factbook and Preliminary Lessons", Federico Sturzenegger (UTDT)

No09 "Countries with international payments ' difficulties: what can the IMF do?"

Andrew Powell (UTDT)

NN08 "The Argentina Crisis: Bad Luck, Bad Management, Bad Politics, Bad Advice",

Andrew Powell (UTDT)

N07 "Capital Inflows and Capital Outflows: Measurement, Determinants, Consequences",

Andrew Powell (UTDT), Dilip Ratha (WB) y Sanket Mohapatra (CU)

No06 "Banking on Foreigners: The Behaviour of International Bank Lending to Latin America, 1985-2000",

Andrew Powell (UTDT), María Soledad Martinez Peria (WB) y Ivanna Vladkova ( IMF)

No05 "Classifying Exchange Rate Regimes: Deeds vs. Words"

Eduardo Levy Yeyati (UTDT) y Federico Sturzenegger (UTDT)

NN04 "The Effect of Product Market Competition on Capital Structure: Empirical Evidence from the

Newspaper Industry", Ernesto Schargrodsky (UTDT)

N03 "Financial globalization: Unequal blessings",

Augusto de la Torre (World Bank), Eduardo Levy Yeyati (Universidad Torcuato Di Tella) y Sergio

L. Schmukler (World Bank)

N02 "Inference and estimation in small sample dynamic panel data models",

Sebastian Galiani (UdeSA) y Martin Gonzalez-Rozada (UTDT)

№1 "Why have poverty and income inequality increased so much? Argentina 1991-2002",

Martín González-Rozada, (UTDT) y Alicia Menendez, (Princeton University). 